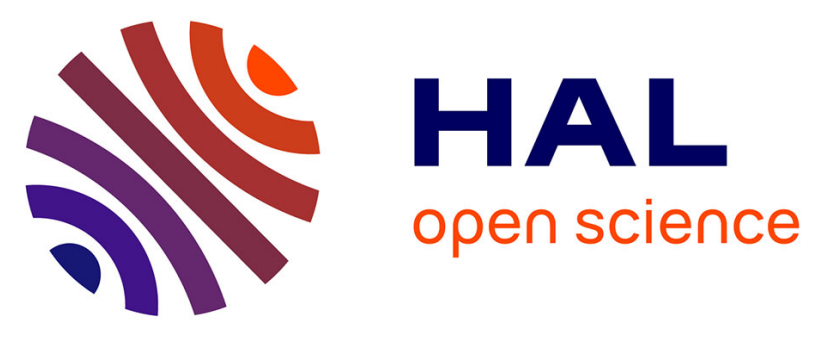

\title{
Soluble guanylyl cyclase is a target of angiotensin II-induced nitrosative stress in a hypertensive rat model
}

Pierre-Antoine Crassous, Samba Couloubaly, Can Huang, Zongmin Zhou, Padmamalini Baskaran, David D. Kim, Andreas Papapetropoulos, Xavier Fioramonti, Walter N. Durán, Annie Beuve

\section{To cite this version:}

Pierre-Antoine Crassous, Samba Couloubaly, Can Huang, Zongmin Zhou, Padmamalini Baskaran, et al.. Soluble guanylyl cyclase is a target of angiotensin II-induced nitrosative stress in a hypertensive rat model. AJP - Heart and Circulatory Physiology, 2012, 303 (5), pp.H597-H604. 10.1152/ajpheart.00138.2012 . hal-01351513

\section{HAL Id: hal-01351513 \\ https://hal.science/hal-01351513}

Submitted on 28 May 2020

HAL is a multi-disciplinary open access archive for the deposit and dissemination of scientific research documents, whether they are published or not. The documents may come from teaching and research institutions in France or abroad, or from public or private research centers.
L'archive ouverte pluridisciplinaire HAL, est destinée au dépôt et à la diffusion de documents scientifiques de niveau recherche, publiés ou non, émanant des établissements d'enseignement et de recherche français ou étrangers, des laboratoires publics ou privés. 


\section{Soluble guanylyl cyclase is a target of angiotensin}

II-induced nitrosative stress in a hypertensive rat model Pierre-Antoine Crassous, Samba Couloubaly, Can Huang, Zongmin Zhou, Padmamalini Baskaran, David D. Kim, Andreas Papapetropoulos, Xavier Fioramonti, Walter N. Durán and Annie Beuve

Am J Physiol Heart Circ Physiol 303:H597-H604, 2012. First published 22 June 2012;

doi: 10.1152/ajpheart.00138.2012

You might find this additional info useful...

This article cites 32 articles, 15 of which you can access for free at:

http://ajpheart.physiology.org/content/303/5/H597.full\#ref-list-1

This article has been cited by 3 other HighWire-hosted articles:

http://ajpheart.physiology.org/content/303/5/H597\#cited-by

Updated information and services including high resolution figures, can be found at:

http://ajpheart.physiology.org/content/303/5/H597.full

Additional material and information about American Journal of Physiology - Heart and Circulatory Physiology can be found at:

http://www.the-aps.org/publications/ajpheart

This information is current as of August 3, 2016.

American Journal of Physiology - Heart and Circulatory Physiology publishes original investigations on the physiology of the heart, blood vessels, and lymphatics, including experimental and theoretical studies of cardiovascular function at all levels of organization ranging from the intact animal to the cellular, subcellular, and molecular levels. It is published 24 times a year (twice monthly) by the American Physiological Society, 9650 Rockville Pike, Bethesda MD 20814-3991. Copyright (C) 2012 the American Physiological Society. ESSN: 1522-1539. Visit our website at http://www.the-aps.org/. 


\title{
Soluble guanylyl cyclase is a target of angiotensin II-induced nitrosative
}

\section{stress in a hypertensive rat model}

\author{
Pierre-Antoine Crassous, ${ }^{1 *}$ Samba Couloubaly, ${ }^{1 *}$ Can Huang, ${ }^{1}$ Zongmin $Z$ Zhou, $^{2}$ Padmamalini Baskaran, ${ }^{1}$ \\ David D. Kim, ${ }^{1}$ Andreas Papapetropoulos, ${ }^{2,3}$ Xavier Fioramonti, ${ }^{1}$ Walter N. Durán, ${ }^{1}$ and Annie Beuve ${ }^{1}$ \\ ${ }^{1}$ Department of Pharmacology and Physiology, New Jersey Medical School, University of Medicine and Dentistry of New \\ Jersey, Newark, New Jersey; ${ }^{2} G$. P. Livanos Laboratory, Department of Critical Care and Pulmonary Services, University of \\ Athens, Greece; and ${ }^{3}$ Laboratory of Molecular Pharmacology, Department of Pharmacy, University of Patras, Patras, Greece
} Submitted 17 February 2012; accepted in final form 19 June 2012

Crassous PA, Couloubaly S, Huang C, Zhou Z, Baskaran P, Kim DD, Papapetropoulos A, Fioramonti X, Durán WN, Beuve A. Soluble guanylyl cyclase is a target of angiotensin II-induced nitrosative stress in a hypertensive rat model. Am J Physiol Heart Circ Physiol 303: H597-H604, 2012. First published June 22, 2012; doi:10.1152/ajpheart.00138.2012.-Nitric oxide (NO) by activating soluble guanylyl cyclase (sGC) is involved in vascular homeostasis via induction of smooth muscle relaxation. In cardiovascular diseases (CVDs), endothelial dysfunction with altered vascular reactivity is mostly attributed to decreased NO bioavailability via oxidative stress. However, in several studies, relaxation to NO is only partially restored by exogenous NO donors, suggesting sGC impairment. Conflicting results have been reported regarding the nature of this impairment, ranging from decreased expression of one or both subunits of $\mathrm{sGC}$ to heme oxidation. We showed that sGC activity is impaired by thiol $S$-nitrosation. Recently, angiotensin II (ANG II) chronic treatment, which induces hypertension, was shown to generate nitrosative stress in addition to oxidative stress. We hypothesized that $S$-nitrosation of sGC occurs in ANG II-induced hypertension, thereby leading to desensitization of sGC to NO hence vascular dysfunction. As expected, ANG II infusion increases blood pressure, aorta remodeling, and protein $S$-nitrosation. Intravital microscopy indicated that cremaster arterioles are resistant to NO-induced vasodilation in vivo in anesthetized ANG II-treated rats. Concomitantly, NO-induced cGMP production decreases, which correlated with $S$-nitrosation of sGC in hypertensive rats. This study suggests that $S$-nitrosation of sGC by ANG II contributes to vascular dysfunction. This was confirmed in vitro by using A7r5 smooth muscle cells infected with adenoviruses expressing sGC or cysteine mutants: ANG II decreases NO-stimulated activity in the wild-type but not in one mutant, C516A. This result indicates that cysteine 516 of sGC mediates ANG II-induced desensitization to NO in cells.

nitric oxide resistance; vascular dysfunction; oxidative stress; hypertension

SOLUBLE GUANYLYL CYCLASE ( $\mathrm{sGC}$ ) is the main receptor for nitric oxide (NO) and the enzyme responsible for the conversion of GTP into cGMP. As such, the NO-receptor sGC is crucially involved in the physiology of the cardiovascular system by modulating vessel tone. Indeed, mice lacking this receptor are hypertensive (5). Oxidative stress is associated with cardiovascular diseases (CVDs) such as hypertension, atherosclerosis, and diabetes. Most oxidative CVDs are accompanied by endothelial dysfunction and impaired vascular reactivity with decreased NO bioavailability. Nonetheless, it should be pointed

\footnotetext{
* P.-A. Crassous and S. Couloubaly contributed equally to this work.

Address for reprint requests and other correspondence: A. Beuve, Dept. of Pharmacology and Physiology, MSB I655 New Jersey Medical School, UMDNJ, 185 South Orange Ave., Newark NJ 07103 (e-mail: annie.beuve@umdnj.edu).
}

out that oxidative stress affects as well the smooth muscle cell (SMC) layers where sGC is expressed. It has been reported that reactive oxygen species (ROS) alter $\mathrm{sGC}$ expression and activity $(19,25,29)$. We $(21)$ have previously shown that in vitro and in vivo $S$-nitrosation of sGC impairs its ability to be activated by NO. In particular, we established that infusion of low therapeutic doses of nitroglycerin in rats for 3 days induces $S$-nitrosation of sGC and correlates with desensitization of sGC to NO stimulation. Importantly, the nitroglycerin treatment was associated with reduced relaxation of arterioles to exogenous NO donors, thus implicating directly sGC activity (22). Association between protein $S$-nitrosation and diseases such as diabetes $(2,30)$ has been reported but association with other CVDs such as hypertension has not been directly addressed. Angiotensin II (ANG II) is a peptide involved in blood pressure regulation and renovascular hypertension $(11,14,18)$ and elevated levels of ANG II induce hypertension. ANG II infusion or treatment, which is clearly established as an inducer of oxidative stress via activation of NADPH oxidases in vivo (17) and in vascular smooth muscle cells such as A7r5 (31), was recently reported to generate global $S$-nitrosation (3).

Most studies have focused on endothelial dysfunction in ANG II-linked hypertension, yet a decreased NO responsiveness, e.g., NO resistance, has been observed and could be due to scavenging of $\mathrm{NO}$ by reactive oxygen species, to decreased sGC activity, or to a decreased sGC expression, as reported in overactive renin-angiotensin system of hypertensive TGR rats (7). Based on our finding that sGC is desensitized to NO by $S$-nitrosation leading to decreased relaxation in vivo and that ANG II generates nitrosative stress, we hypothesized that sGC activity could be impaired via $S$-nitrosation in ANG II-induced hypertension thereby contributing to decreased vascular reactivity. Thus we assayed in ANG II-induced hypertension rat model, the level of $S$-nitrosation of the sGC, whether sGC was desensitized to NO, and measured vascular NO resistance in vivo (so far studies by others on NO responsiveness and vascular reactivity have been done on isolated vessels in organ chamber). In parallel, we explored the molecular mechanism of sGC desensitization by ANG II in A7r5 SMC, which are depleted for endogenous sGC, by infecting the SMC with adenoviruses expressing wild-type (WT) sGC and Cys mutants of sGC and measuring NO-stimulated sGC activity in the infected cells treated or not with ANG II.

\section{MATERIALS AND METHODS}

Animal model. Sprague Dawley (SD) male rats (160-230 g, Charles River) were treated with ANG II $\left(0.7 \mathrm{mg} \cdot \mathrm{kg}^{-1} \cdot \mathrm{day}^{-1}, 7\right.$ days $)$ or with vehicle $(0.9 \% \mathrm{NaCl}, 7$ days) via mini-osmotic pump (Alzet, model 2002, 
Durect; Cupertino, CA) implanted subcutaneously on animal anesthetized with sodium pentobarbital $(50 \mathrm{mg} / \mathrm{kg}$ ip). The procedure was initiated when the withdrawal reflex was no longer present indicating an adequacy of anesthesia; the respiratory rate was monitored as well. Buprenorphine hydrochloride $(0.03 \mathrm{mg} / \mathrm{kg} \mathrm{sc})$ was administered as analgesic after surgery. Seven days after pump implantation, rats were anesthetized (sodium pentobarbital sodium; $50 \mathrm{mg} / \mathrm{kg}$ ip) and bled by abdominal aorta incision. Tissues (aorta, lungs, and mesenteric vasculature) were removed and washed in PBS and snap frozen in liquid nitrogen for storage or processed for cryosection as detailed below.

All experimental procedures conform to the Guide for the Care and Use of Laboratory Animals published by the United States National Institutes of Health and were approved by University of Medicine and Dentistry of New Jersey Institutional Animal Care and Use Committee (\#10085D0114).

Blood pressure. Mean arterial pressure (MAP) was determined by tail-cuff plethysmography (Kent Scientific, CODA system) on nonanesthetized rats trained for a week before surgery of pump implantation. Measures were performed before implantation of the osmotic pump and from 2 to 7 days after. Blood pressure was also monitored on anesthetized rats (pentobarbital, $50 \mathrm{mg} / \mathrm{kg}$ ip) via a catheter implanted in left carotid artery and connected to a Power Lab Pressure Monitor (AD instruments, Colorado Springs, CO) 7 days after pump implantation.

Intravital microscopy. SD male rats (160-230 g, Charles River) were anaesthetized with sodium pentobarbital ( $50 \mathrm{mg} / \mathrm{kg}$ ip). The right cremaster muscle was prepared for intravital microscopy $(10,26)$. Pentobarbital sodium was continuously administered $(0.03 \mathrm{mg} / \mathrm{min}$, $0.1 \mathrm{ml} / \mathrm{h} \mathrm{iv}$ ) via catheter implanted in right jugular veins to maintain anesthesia. To assess the adequacy of anesthesia during the whole experiment, parameters such as responsiveness, blood pressure, respiratory rate, and heart rate were monitored. The recording system comprises an Optronics TEC-470 microscope camera (Optronics, Goleta, CA), a Sony monitor, and a MetaMorph image system (Universal Imaging, Downingtown, PA) for computer recording directly from the microscope camera and for image processing. Arteriolar luminal diameter was measured as the width of the transilluminated blood column using the MetaMorph image system. Two to three arterioles were studied per animal. Baseline diameters were normalized to a value of one. For each vessel, the experimental diameter was expressed as the ratio of baseline diameter (relative luminal diameter). To compare diameters before and after each application, diameters were measured at the same place in the arterioles of interest. Luminal diameter was allowed to return fully to basal value before a successive NO-donor application. At the completion of the experiment, rats were killed by an overdose of sodium pentobarbital $(150 \mathrm{mg} / \mathrm{kg}$ iv) while they were under anesthesia.

S-nitrosation detection in tissues. Aortas from control or ANG IItreated rats were embedded in Tissue-Tek O.C.T compound (Sakura Finetek) and frozen. Ten-micrometer transversal cryosections were mounted on glass slides (Superfrost plus, VWR) and processed for $S$-nitrosation detection.

To determine the level of $S$-nitrosation in situ, transversal cryosections were fixed and permeabilized with $3 \%$ paraformaldehyde and $0.2 \%$ Triton $(10 \mathrm{~min})$ and then incubated in $1 \%$ BSA for $1 \mathrm{~h}$. Slides were treated overnight with primary antibody (rabbit anti-S-nitrosation, Alpha Diagnostic no. NISC 11-A at 1/100 dilution in PBS with $1 \%$ BSA) followed by $1 \mathrm{~h}$ incubation with secondary antibody (Alexafluor 594 Invitrogen, 1/100 dilution in PBS with 1\% BSA). A coverslip was applied on top of preparation with Prolong gold antifading containing DAPI (Invitrogen). Cryosections of aorta from ANG II-treated rats were used for negative control as follows: slides were treated with ascorbate $(10 \mathrm{mM}, 1 \mathrm{~h})$ to reduce $S$-nitrosated cysteine of proteins prior to incubation with anti-S-nitrosation and secondary antibodies as described by Ckless et al. (4).

To confirm $S$-nitrosation in situ, aorta transversal cryosections were fixed and permeabilized with $3 \%$ paraformaldehyde and $0.2 \%$ Triton for $10 \mathrm{~min}$. After wash, slides were incubated in PBS, $0.4 \mathrm{mM}$ EDTA, $0.04 \mathrm{mM}$ neocuproine, containing $1 \%$ SDS and $40 \mathrm{mM} \mathrm{N}$-ethylmaleimide (NEM) for $30 \mathrm{~min}$ at $40^{\circ} \mathrm{C}$. After the excess of NEM was washed, $S$-nitrosation bonds were switched to $S$-biotin bonds: slides were incubated in PBS-EDTA-Neocuproine as above with $10 \mathrm{mM}$ ascorbate and $0.1 \mathrm{mM}$ HPDP-biotin for $1 \mathrm{~h}$. After wash and blocking (PBS, 1\% BSA, $1 \mathrm{~h}$ ), biotin was detected by a primary antibody anti-biotin (Abcam, 1/250, overnight) followed by secondary antibody Alexafluor 594. Images were obtained with 200M Axiovert fluorescence microscope (Zeiss) and analyzed with Axiovision software.

$s G C$ activity. cGMP production in tissues and sGC activity in cells were assayed as previously (22). cGMP production was measured by radioimmunoassay in lungs from control or ANG II-treated rats, incubated with $0.5 \mathrm{mM}$ IBMX (a wide spectrum phosphodiesterase inhibitor) and treated with $\mathrm{NO}$ donor $[0.1 \mathrm{mM}$ diethylamine-NO (DEA-NO) or $0.01 \mathrm{mM} S$-nitroso- $N$-acetyl-penicillamine (SNAP)] for $1 \mathrm{~h}$ at $37^{\circ} \mathrm{C}$. The reaction was stopped with $2.5 \%$ perchloric acid. Following neutralization with $0.75 \mathrm{~N} \mathrm{KOH}$, cGMP and cAMP were measured by radioimmunoassay. cAMP, measured in the same samples, was used to normalize cGMP data as cAMP is a good indicator of tissue amount used in the assay and is independent of SNAP or DEA-NO stimulation and because the increase in cAMP levels in response to NO is negligible compared with increased NO-dependent cGMP levels . Assays of protein concentration (before perchloric acid lysis) correlated with estimated cAMP levels. sGC activity was determined by formation of $\left[\alpha-{ }^{32} \mathrm{P}\right] \mathrm{cGMP}$ from $\left[\alpha-{ }^{32} \mathrm{P}\right] \mathrm{GTP}$ under basal (unstimulated) and NO-stimulated (DEA-NO; $1 \mu \mathrm{M}$ ) conditions for $5 \mathrm{~min}$ at $33^{\circ} \mathrm{C}$. Typically, $40 \mu \mathrm{g}$ of cytosol were used in each assay reaction. Reaction mix contained $50 \mathrm{mM}$ HEPES $\mathrm{pH} 8.0,5 \mathrm{mM}$ $\mathrm{MgCl}_{2}$, and $0.5 \mathrm{mM} \mathrm{GTP}$.

Biotin switch assay. sGC $S$-nitrosation was determined by the biotin switch assay (9) as modified by us; 0.5 to $1 \mathrm{mg} / \mathrm{ml}$ proteins from lungs or cells lysate were incubated in blocking buffer $(250 \mathrm{mM}$ HEPES, $150 \mathrm{mM} \mathrm{NaCl}, 0.1 \mathrm{mM}$ neocuproine, $1 \mathrm{mM}$ EDTA, 2.5\% SDS, and $50 \mathrm{mM} \mathrm{NEM}$ ) at $40^{\circ} \mathrm{C}$ for $30 \mathrm{~min}$ in the dark. Proteins were
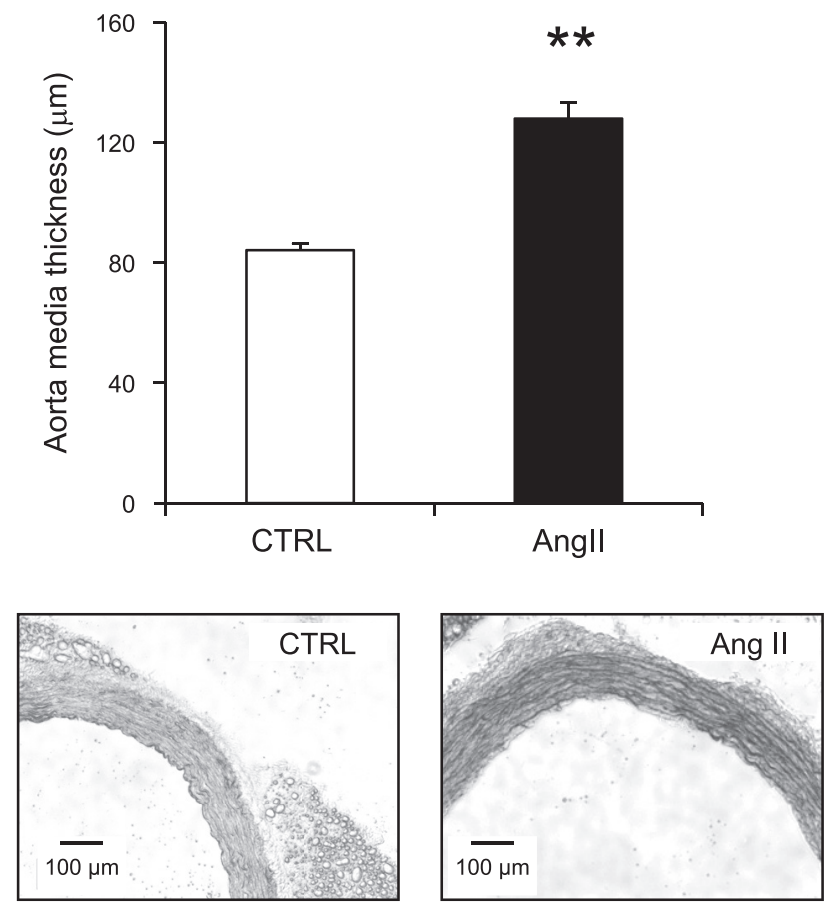

Fig. 1. ANG II induces aorta remodeling. Width of the media of thoracic aorta from control (CTRL; $n=4$ ) and ANG II-treated (ANG II; $n=5$ ) rats were determined on transversal cryosections (bright field, $\times 10$ magnification). $* * P<0.0005$. 
precipitated in $3 \mathrm{vol}$ of acetone to remove NEM and resuspended in 25 $\mathrm{mM}$ HEPES containing $1 \%$ SDS and then treated with HPDP-biotin $(0.2 \mathrm{mM})$ with or without ascorbate $(1 \mathrm{mM})$ for $1 \mathrm{~h}$ at room temperature. After addition of $2 \mathrm{vol}$ of neutralizing buffer $(20 \mathrm{mM}$ HEPES, $100 \mathrm{mM} \mathrm{NaCl}, 1 \mathrm{mM}$ EDTA, and $0.5 \%$ Triton), biotinylated proteins were purified with streptavidin-agarose resin beads (Thermo Scientific) for $1 \mathrm{~h}$ and eluted in Laemmli reducing buffer (Sigma). Proteins incubated with HPDP-biotin without ascorbate were used as negative control for the experiment, e.g., specificity of biotinylation.

Western blot. Proteins from lungs or mesenteric vasculature from control or ANG II-treated rats or from biotin switch assay or cell lysates were separated by SDS-PAGE and transferred to nitrocellulose membrane. After $1 \mathrm{~h}$ blocking in PBS containing 5\% BSA, membranes were incubated with sGC anti- $\alpha$-subunit $1 / 10,000$ (Sigma), sGC anti- $\beta$-subunit $1 / 1,000$ (Cayman Chemical), or $\beta$-actin $1 / 5,000$
(Sigma). The appropriate secondary antibody coupled with peroxidase (anti-rabbit or anti-mouse 1/10,000, Amersham) allowed protein detection by chemiluminescence with ECL kit (GE Healthcare). Signal quantification of blots were performed with ImageJ software (W. S. Rasband; National Institutes of Health, Bethesda, MD).

Cell culture, infection and lysates preparation. Rat primary vascular SMC (A7r5; ATCC), which do not express detectable sGC, were used between passages 4 to 10 . They were grown in DMEM (with L-glutamine and 5\% BSA) until $80 \%$ confluence and infected with 1 to 4 multiplicity of infection of adenoviruses expressing $\alpha$-WT or $\alpha$ C516A-subunit with $\beta$-WT subunit of sGC. $48 \mathrm{~h}$ after infection, cells were harvested in "sGC activity buffer" [50 mM HEPES, 150 $\mathrm{mM} \mathrm{NaCl}$, antiprotease inhibitors (tablet, Roche), and $35 \mu \mathrm{g} / \mathrm{ml}$ PMSF] or "biotin switch buffer" [250 mM HEPES, $150 \mathrm{mM} \mathrm{NaCl}, 1$ $\mathrm{mM}$ EDTA, $0.1 \mathrm{mM}$ neocuproine, antiprotease inhibitor (tablet,
A

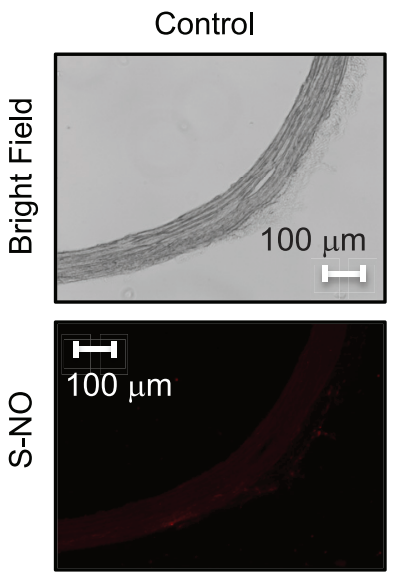

Ang II
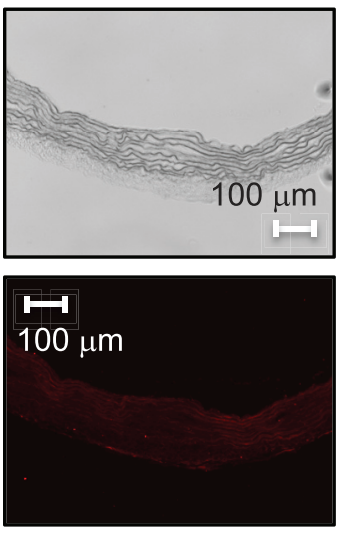

B

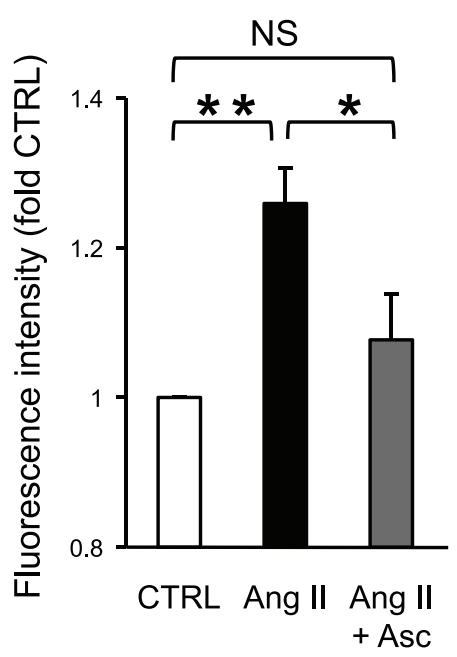

C
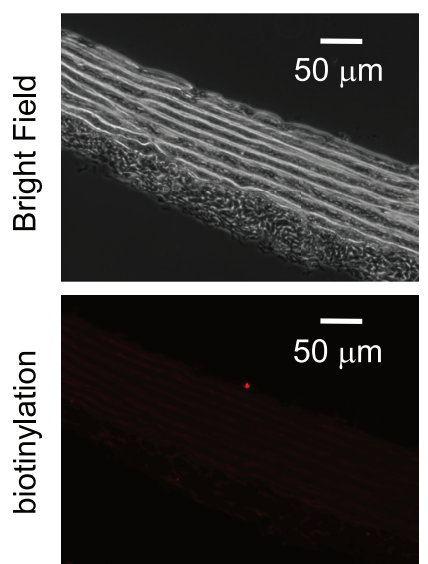

Ang II + Asc
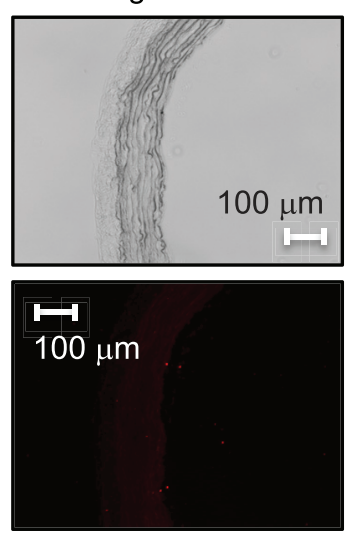
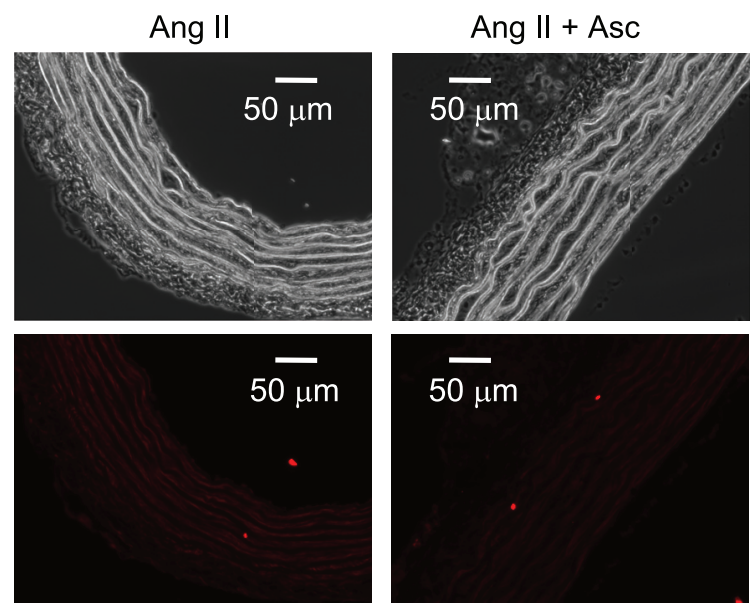

Fig. 2. S-nitrosation (S-NO) is increased in ANG II-treated rats. A: representative images $(\times 10)$ of transversal cryosection of thoracic aorta from control or ANG II-treated rats. Aortas were incubated with anti-S-NO and revealed with secondary antibody Alexafluor594. As control for specificity of S-NO detection, aortas from ANG II-treated rats were preincubated for $1 \mathrm{~h}$ with $10 \mathrm{mM}$ ascorbate (Asc), which reduces S-NO bonds. Corresponding bright field images are shown at top. B: fluorescence image analysis from aorta cryosections of control (CTRL, $n=5)$, ANG II $(n=6)$, and ANG II + Asc $(n=5)$ indicates significant and specific S-NO by ANG II. $* * P<0.005$, ANG II vs. CTRL; $* P<0.05$, ANG II vs. ANG II + Asc; NS: nonsignificant, CTRL vs. ANG II + Asc. Signal intensity was quantified at same exposure time between groups and normalized to control. $C$ : representative images $(\times 20)$ of S-NO level detected by biotin switch assay on transversal cryosection of thoracic aorta from control or ANG II-treated rats. Biotin switch assay was performed on aortic cryosections, and the level of biotin was detected by immunofluorescence using a primary antibody anti-biotin (Abcam) revealed by secondary antibody Alexafluor594, as described in MATERIALS AND METHODS. Same exposure times were used in each experiment. As control for specificity of S-NO detection, aortas from ANG II-treated rats were preincubated with $10 \mathrm{mM}$ ascorbate (Asc). Corresponding bright field images are shown at top. 
Roche), and $35 \mu \mathrm{g} / \mathrm{ml}$ PMSF] and sonicated on ice. Debris were removed by centrifugation at $16000 \mathrm{~g}$ for $5 \mathrm{~min}$ at $4^{\circ} \mathrm{C}$, and the supernatants (cytosolic fraction) were aliquoted and snap frozen. Protein concentration was determined by Bradford method. Adenoviral construction and sitedirected mutagenesis were done as in $(21,32)$.

Statistical analysis. Data are expressed as means \pm SE. For statistical analysis, unpaired Student's $t$-test was used to compare ANG II-treated and control groups and one-way ANOVA (Tukey's post hoc test) was used to compare more than two groups. Analysis was done with SigmaPlot 11.0. $P<0.05$ was considered significant.

\section{RESULTS}

ANG II-induced hypertension causes oxidative/nitrosative stress. We analyzed MAP, oxidative/nitrosative stress level, and aortic remodeling in control rats and in rats treated with ANG II. Administration of ANG II significantly increased MAP relative to control rats [tail-cuff measurement: ANG II $(n=4) 140.9 \pm 9.7$ vs. control $(n=4) 100.8 \pm 3.4 \mathrm{mmHg}$; $P<0.005]$. The increase in MAP in ANG II-treated rats was confirmed by recording carotid pressure directly via catheter on anesthetized rats (control $114 \pm 3$ vs. ANG II $158 \pm 8 \mathrm{mmHg}$; $P<0.0005 ; n=7)$. Vascular hypertrophy was demonstrated by the significant enlargement of the aortic media wall width in ANG II-treated rats (Fig. 1) with extensive remodeling of the aorta wall (Fig. 1, bottom). We have previously determined in vitro that $S$-nitrosation of sGC causes a decreased response to NO; thus we measured whether $S$-nitrosation following ANG II infusion occurs. Using immunocytochemistry with anti-S-nitrosation antibodies, we showed that ANG II significantly increases the level of $S$-nitrosation in the media of aorta. The specificity of $S$-nitrosation detection was confirmed by treatment with ascorbate (Fig. 2, $A$ and $B$ ). This increase in $S$-nitrosation levels was confirmed by conducting a biotinswitch assay on the aortic tissues (Fig. 2C). These results indicate that at day 7 of ANG II treatment, rats have developed hypertension, nitrosative stress, and aorta remodeling. These results confirm previous studies $(3,16,17,27,28)$ and show that ANG II-induced hypertension is an adequate model to study the relevance of oxidative and nitrosative stress-induced alterations on sGC activity and their impact on vascular pathology.

NO resistance in arterioles of cremaster muscle. To assay whether ANG II-induced hypertension correlates with reduced vascular reactivity to $\mathrm{NO}$, we measured in vivo arterioles vasodilation to NO donors by intravital microscopy of the cremaster muscle vasculature. As shown in Fig. 3, the arterioles of control rats relaxed in response to the NO donors SNAP $(10 \mu \mathrm{M})$ and DEA-NO $(1 \mu \mathrm{M})$; in sharp contrast, the vasodilatory response to NO of arterioles was significantly blunted in ANG II-treated rats. These data indicate that NO resistance takes place in ANG II-induced hypertension model and suggest that ANG II treatment diminishes the sGC response to NO in arterioles of the cremaster muscle. We used cremaster muscle because it is a tissue well adapted to in vivo measurement of vasodilation by intravital microscopy. The baseline mean diameters of the selected arterioles were $49 \pm 2 \mu \mathrm{m}$ in the control group and $46 \pm 4 \mu \mathrm{m}$ in the ANG II treated group.

$N O$-dependent cGMP production is reduced in ANG II-treated rats. To assay whether impaired vascular response to NO in the ANG II-treated rat was due to impaired response of sGC to NO, cGMP production was measured under basal (no stimulation) and

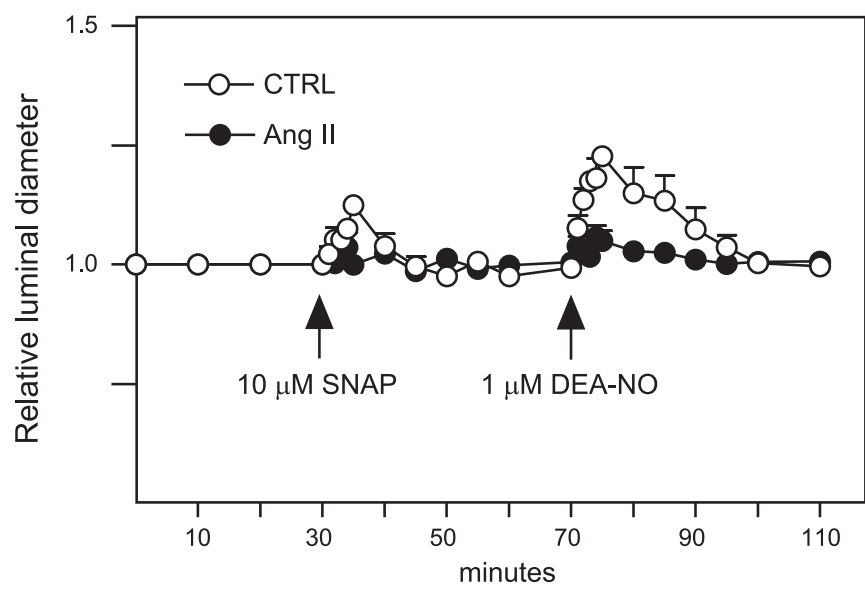

Fig. 3. Arterioles are resistant to NO-induced vasodilation in ANG II-treated rats. Vascular vasodilation in response to $\mathrm{NO}$ was evaluated in vivo by intravital microscopy on cremaster muscle arterioles. $S$-nitroso- $N$-acetyl-penicillamine (SNAP; $10 \mu \mathrm{M}$ ) or diethylamine-NO (DEA-NO; $1 \mu \mathrm{M}$ ) was applied topically on cremaster vasculature of control (CTRL, O, $n=5$ ) or ANG II-treated (ANG II, $\bullet, n=5$ ) rats for $5 \mathrm{~min}$. A 30-min recovery was allowed between the two NO-donor applications. Relative luminal diameter from 2 to 3 arterioles was assessed for each preparation. Baseline mean diameters of the selected arterioles were $49 \pm 2 \mu \mathrm{m}$ in the control group and $46 \pm 4 \mu \mathrm{m}$ in the ANG II treated group and not significantly different. The reduced increase in relaxation in response to SNAP and DEA-NO in ANG II-treated rats was significant, $P<0.05$ and $P<0.0001$, respectively.

NO-stimulated conditions in lungs. Lungs were chosen because they are highly vascularized tissues with high expression of sGC, facilitating cGMP detection. Figure $4 A$ indicates that basal cGMP production was similar in lung of control and ANG II-treated rats whereas cGMP production in response to the NO donors SNAP $(100 \mu \mathrm{M})$ and DEA-NO $(10 \mu \mathrm{M})$ was drastically reduced in ANG II-treated rats. No significant change in sGC expression was observed between the Ctrl and ANG II-treated rat lungs (Fig. 4B). There was also no change in sGC expression in other vasculature tissues such as mesentery (Fig. 4B). These results indicate that NO-stimulated sGC activity per se is impaired in ANG II-induced hypertensive rats.

$s G C$ is nitrosated in ANG II hypertensive rats. We next investigated whether sGC was $S$-nitrosated under these conditions. Using the biotin-switch assay (see MATERIALS AND METHODS and Ref. 9), we detected a strong $S$-nitrosation of sGC in the lungs of ANG II-treated rats compared with untreated rats (Fig. 5, $A$ and $B$ ). Similar levels of $\mathrm{sGC}$ in input (biotinylated samples from ANG II and untreated rats) confirm that ANG II infusion did not modify sGC expression (Fig. 5B). Those data indicate that ANG II treatment leads to $S$-nitrosation of sGC.

These results show a correlation between in vivo blunted NO-induced relaxation of arterioles (NO resistance), decreased NO-dependent sGC activity, and increased sGC $S$-nitrosation in ANG II-induced hypertensive rats. To determine the potential causal relationship between ANG II treatment and NO resistance via thiol oxidation of $\mathrm{sGC}$, we used an in vitro adenoviruses/cell system.

sGC is desensitized to NO in A7r5 cells treated with ANG II. A7r5 SMC, which do not express detectable level of sGC, were infected with adenoviruses expressing the $\alpha$-and $\beta$-WT subunits of sGC. After $48 \mathrm{~h}$, cells were treated or not with $100 \mathrm{nM}$ ANG II for $4 \mathrm{~h}$ and their cytosolic fractions were prepared (32). As shown on Fig. $6 A$, basal sGC activity was similar in the 
A

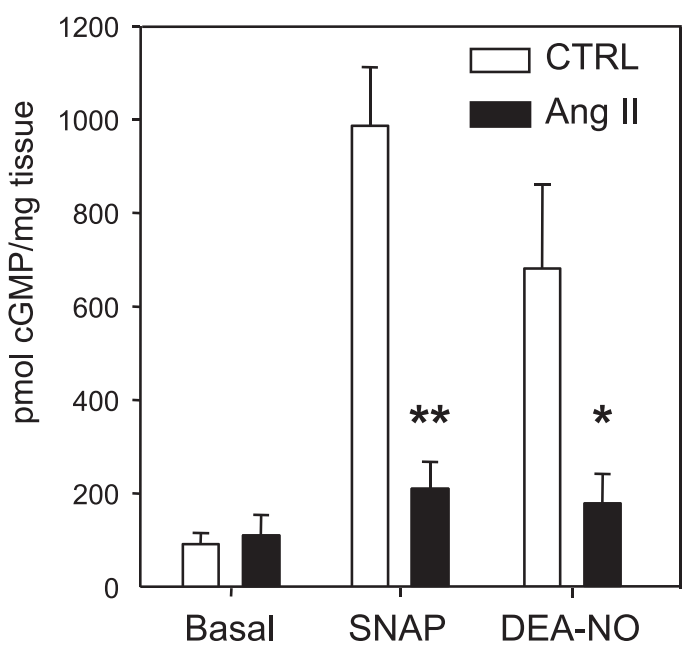

B
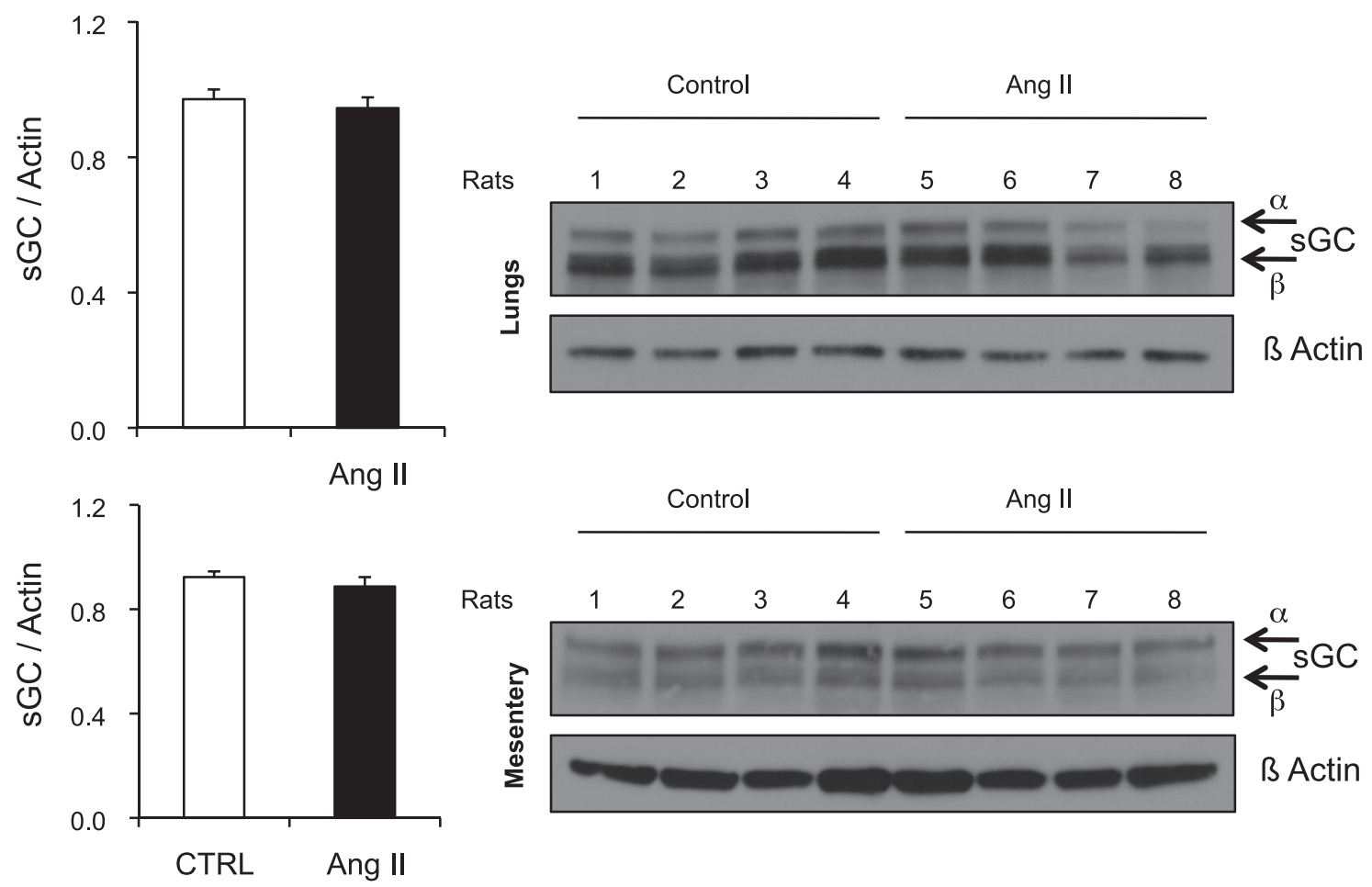

Fig. 4. NO-induced cGMP production is decreased in ANG II treated rats. A: lung of control (CTRL, $n=5$ ) and ANG II-treated (ANG II, $n=5$ ) rats were incubated with IBMX $(500 \mu \mathrm{M})$ for $15 \mathrm{~min}$, followed, or not (Basal), by incubation with NO donors (SNAP, $100 \mu \mathrm{M}$; DEA-NO, $10 \mu \mathrm{M})$ for $1 \mathrm{~h}$ at $37^{\circ} \mathrm{C}$. cGMP production was measured by radioimmunoassay; ${ }^{*} P<0.05$; $* * P<0.001$. $B$ : Western Blots (WB) with antibodies against $\alpha$ - and $\beta$-subunit of sGC and $\beta$-actin indicate that sGC expression is similar in lysate from lung (top) and mesentery vasculature (bottom) of control and ANG II-treated rats $(n=8$ in lungs and $n=4$ in mesentery; $P>0.05$, CTRL vs. ANG II).

cytosolic fraction of untreated and ANG II-treated samples. On the other hand, NO-stimulated sGC activity was markedly inhibited $(49.7 \pm 4.4 \%)$ by ANG II treatment, while expression of sGC in both cytosolic fractions was similar (inset). In parallel, biotin switch assay showed that ANG II treatment increased $S$-nitrosation of sGC (data not shown). Those results indicate that ANG II affects directly NO-stimulated sGC ac- tivity, potentially via $S$-nitrosation, in agreement with results obtained in vivo.

Cysteine 516 (C516) in the $\alpha$-subunit of $s G C$ mediates $A N G$ II-dependent desensitization to NO. To establish a causal relationship between $S$-nitrosation of sGC by ANG II and its desensitization to $\mathrm{NO}$, we conducted site directed mutagenesis of C516, a cysteine newly identified by mass spectrometry as 
A

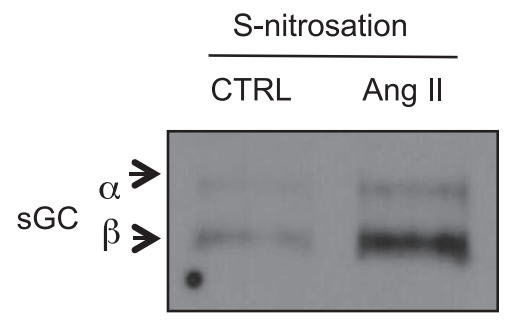

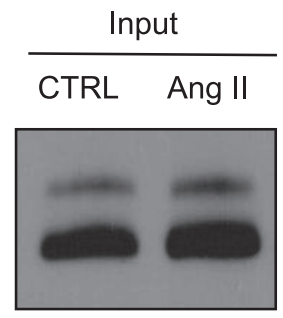

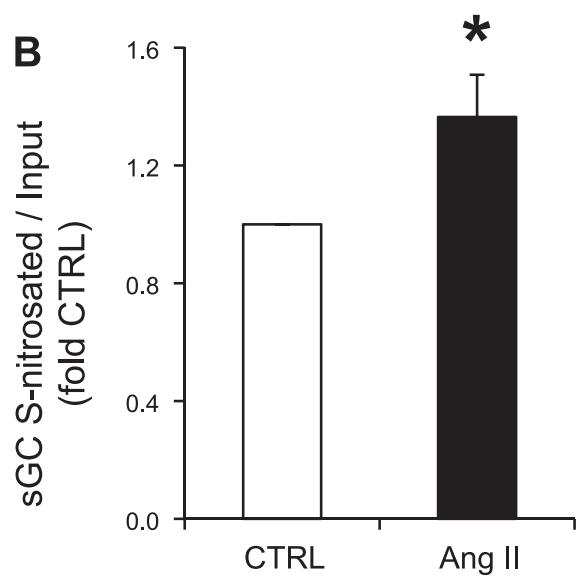

Ang II

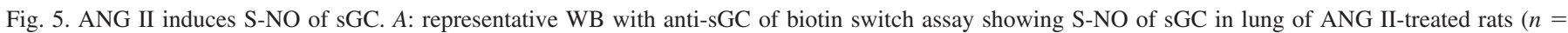

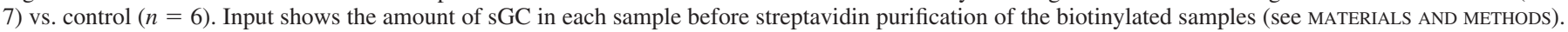
$B$ : level of sGC S-NO in lung from control $(n=6)$ or ANG II-treated rats $(n=7)$ normalized to input and expressed as fold of CTRL; $* P<0.05$.

$S$-nitrosated and highly conserved in the catalytic domain of sGC. Adenovirus containing the C516A mutation in the $\alpha$ subunit was coinfected with the WT $\beta$-subunit. Cytosolic fractions of the infected A7r5 SMC treated or not with ANG II were prepared as above. Figure $6 B$ indicates that replacement of C516 with Ala confers resistance to NO desensitization, as no decrease in NO-stimulated sGC activity was observed following ANG II treatment. Expression of $\alpha \mathrm{C516 \textrm {A } /} \beta$ was unchanged by ANG II treatment (Fig. 6B, inset). This result shows that ANG II affects NO-stimulated sGC activity via a thiol-dependent mechanism. It should be noted that in the absence of treatment, NO-stimulated activity was similar between WT and C516A mutant $(10,475 \pm 1,435$ vs. 9,874 \pm $\left.1,328 \mathrm{pmol} \mathrm{cGMP} \cdot \mathrm{min}^{-1} \cdot \mathrm{mg}^{-1}\right)$. This is important as it indicates that in the absence of ANG II-induced stress, the NOstimulated sGC activity is not affected by the mutation C516A. We conducted the same experiment with adenovirus expressing mutant $\alpha \mathrm{C} 243 \mathrm{~A}$, as $\mathrm{C} 243$ is known to mediate sGC desensitization following treatment with $S$-nitrosocysteine (CSNO) or nitroglycerin $(21,22)$. However, ANG II affected NO-stimulated activity of C243A as it did for WT (not shown), suggesting that $\mathrm{C} 243$ does not participate in the ANG II desensitization effect.

\section{DISCUSSION}

In this study, we tested the hypothesis that sGC activity could be impaired by $S$-nitrosation leading to decreased vascular reactivity in vascular diseases associated with generation of oxidative/nitrosative stress. We used a model of ANG II-induced hypertension because it increases oxidative stress via activation of NAD[P]H oxidase (17) and $S$-nitrosation in tissues (3). Our data (Fig. 2) confirmed that nitrosative stress occurs in vascular SMC, the site of expression of $\mathrm{sGC}$ in the vascular system. Many studies have reported that overactivation of the renin-angiotensin system, as mimicked in ANG II-induced hypertension model, leads to endothelial dysfunction with decreased NO bioavailability. An impaired NO production (15) or NO being scavenged by reactive oxygen species has been proposed as an explanation of the decreased vascular reactivity and of the increased vascular wall remodeling that takes place in hypertension (for recent reviews see
Refs. 20, 23). Meanwhile, it was reported that NO responsiveness was also decreased by this overactive renin-angiotensin system suggesting impairment downstream of NO production $(1,8)$. Some groups $(1,7,15)$ have proposed that this vascular desensitization to NO was due to downregulation of $\mathrm{sGC}$, and recently one group (13) observed that stimulation of sGC by the NO-independent activator (Bay 41-2272) could prevent cardiovascular remodeling in a similar ANG II hypertensive animal model. These observations pointed to a role of $\mathrm{sGC}$ in ANG II-induced hypertension, but the mechanism by which sGC was involved in decreased NO responsiveness remained controversial.

Our studies show that ANG II infusion induces NO resistance in arterioles of the rat cremaster muscle that was characterized by a significant decrease in vasodilation in response to two different types of NO donors. Importantly, we studied the vascular NO resistance in resistant arterioles (cremaster muscle arterioles) because they are largely involved in blood pressure regulation and in ANG II hypertensive effect (24) whereas most of previous investigations focused on conduit vessels (aorta and arteries). Indeed, remodeling of the arteriolar wall and changes in smooth muscle reactivity is associated with vascular resistance during the development of hypertension $(12,33)$. More importantly, to our knowledge, this is the first report showing that ANG II impairs vascular reactivity via decreased NO responsiveness in vivo, as previous studies (3, 15) used an ex vivo system in which isolated blood vessels reactivity is measured in organ chamber. Blunted arterioles responsiveness to $\mathrm{NO}$ in hypertensive rats is unlikely due to NO scavenging because of the high NO donors concentrations we used (10 $\mu \mathrm{M}$ SNAP and $1 \mu \mathrm{M}$ DEA-NO). This strongly suggested an impairment of sGC and led us to investigate its activity.

The rats treated with ANG II exhibited a significant decrease in NO-dependent cGMP production. Those experiments were done in the presence of IBMX, indicating that sGC activity per se was affected rather than activation of phosphodiesterase to explain the decreased cGMP (6). These results obtained in rat lungs are in agreement with the recently reported decrease of cGMP production in aorta of ANG II-induced hypertension mice (3). Of note, the level of expression of $\mathrm{sGC}$ was not 

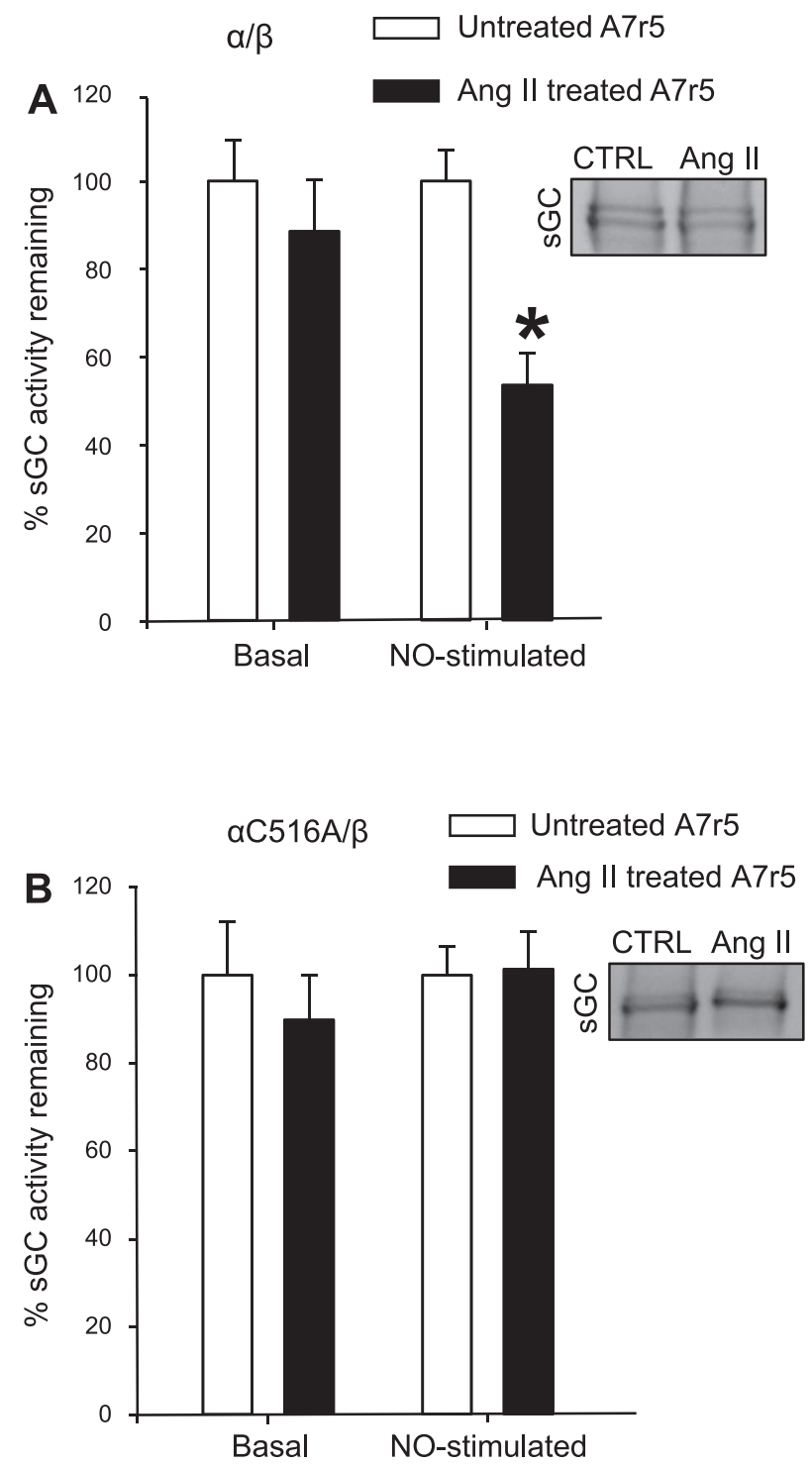

Fig. 6. ANG II-induced decrease in NO-stimulated sGC activity in A7r5 cells is mediated by $\alpha \mathrm{C} 516$. A: basal and NO stimulated sGC activity was measured in the cytosolic fraction of A7r5 cells infected with WT $\alpha / \beta$ and untreated (opened bar) or treated (filled bar) with ANG II (100 nM, $4 \mathrm{~h})$. B: same experiment but cells were infected with mutant $\alpha \mathrm{C} 516 \mathrm{~A} / \beta$. The effect of desensitization is expressed as the percentage of activity remaining. NO donor DEA-NO was used at $1 \mu \mathrm{M}$. Results are the mean of 5-8 activity measurements for each condition; each assay was done in duplicate and from 4 independent infections; $* P<0.001$. Insets: WB with anti-sGC showing that expression of sGC WT and mutant is similar and not affected by ANG II treatment.

decreased in lung or mesenteric vasculature of the ANG II-treated rats. This result is different from a previous study (15) showing that ANG II infusion led to decreased expression of sGC; this discrepancy might be due to a higher concentration used by the other group ( $1 \mathrm{mg}$ vs. $\left.0.7 \mathrm{mg} \cdot \mathrm{day}^{-1} \cdot \mathrm{kg}^{-1}\right)$ and the tissues analyzed were aortic sections. Altogether these results indicate that the NO-dependent activity of sGC in SMC is directly impaired in the ANG II induced hypertension model and is associated with a decrease in NO-dependent relaxation in vivo. Thus the next question was the mechanism by which the NO-stimulated sGC activity was decreased.
We (21) recently demonstrated that $S$-nitrosation of sGC causes desensitization to NO stimulation, and therefore, we hypothesized that $S$-nitrosation of sGC by ANG II could be the cause of the reduced NO responsiveness. In addition, global $S$-nitrosation was observed in homogenates of aortic tissues in ANG II-treated mice (3). We confirmed by another means, immunocytochemistry with anti-S-nitrosation antibodies and biotin switch assay in situ, that ANG II infusion led to significant $S$-nitrosation of aortic tissues (Fig. 2). More importantly, we specifically detected sustained $S$-nitrosation of sGC (Fig. 5 ), thus establishing a potential causal relationship between decrease NO vascular reactivity and $S$-nitrosation of sGC by ANG II.

To further examine whether the thiols of sGC were a specific target of ANG II-induced nitrosative stress and a potential explanation for decreased NO-stimulated activity, we used A7r5 cells that do not express detectable level of sGC and were previously shown to respond to ANG II treatment (31). Infection with wild-type sGC-expressing adenoviruses and treatment with ANG II leads to $50 \%$ desensitization of sGC to NO (the basal activity remained unchanged, Fig. 6A) and $S$-nitrosation of sGC. We established that this NO desensitization of sGC was thiol dependent as a single mutation of a cysteine in sGC (C516A) confers resistance to the ANG II-induced sGC desensitization in A7r5 SMC (Fig. 6B). This mutational analysis establishes, in vitro, a causal relationship between ANG II-induced NO desensitization and thiol oxidation of sGC. This study is the first to establish a link between ANG II treatment and thiol-dependent inactivation of sGC via $S$-nitrosation of sGC, yet further experiments using C516A knock-in animals will be necessary to establish a causal relationship in vivo in ANG II-induced hypertension model.

Interestingly, the replacement of another Cys in the $\alpha$-subunit of sGC, C243, which is known to mediate desensitization induced by treatment with the nitrosating agent CSNO and with nitroglycerin $(21,22)$ does not prevent ANG II-induced desensitization as C516A does. This suggests that the $S$ nitrosation is specific and a function of the type of nitrosative stress. We speculate that $\mathrm{C} 243$ is nitrosated by low molecular weight $S$-nitrosothiols such as CSNO but might not be modified by ANG II-induced nitrosative stress, potentially in the form of $\mathrm{N}_{2} \mathrm{O}_{3}$. Alternatively, the thiol of $\mathrm{C} 243$ might not be as sensitive to oxidation (for creation of a reactive thiolate) as C516. Further experiments comparing sGC $S$-nitrosation status under various oxidative and nitrosative stresses are needed to address this question.

In summary, our in vivo and in vitro studies demonstrate that nitrosation of sGC correlates with NO resistance syndrome in ANG II-induced hypertension and that Cys 516 of the $\alpha$ subunit of sGC is a specific target of ANG II-induced oxidative/nitrosative stress.

\section{ACKNOWLEDGMENTS}

We thank Dr. Erin J. Heckler and Andrea Wecker for help with some of the figures.

Present address of P. Baskaran: College of Health Sciences, School of Pharmacy, University of Wyoming Dept. 3375, 1000 East University Avenue, Laramie, WY 82071.

Prsent address of X. Fioramonti: Centre des Sciences du Goût et de l'Alimentation (CSGA) UMR 6265 CNRS, 1324 INRA-uB, Dijon, France. 


\section{GRANTS}

This work was supported by National Institutes of Health Grants GM067640, HL-089771 (to A. Beuve), and HL-070634 (to W. N. Durán) and the Founders Affiliate of the American Heart Association (postdoctoral fellowship to P. A. Crassous).

\section{DISCLOSURES}

No conflicts of interest, financial or otherwise, are declared by the author(s).

\section{AUTHOR CONTRIBUTIONS}

Author contributions: P.-A.C., S.C., A.P., X.F., W.N.D., and A.B. conception and design of research; P.-A.C., S.C., C.H., Z.Z., P.B., D.D.K., and X.F. performed experiments; P.-A.C., S.C., C.H., Z.Z., P.B., D.D.K., X.F., and A.B. analyzed data; P.-A.C., S.C., C.H., P.B., D.D.K., A.P., X.F., W.N.D., and A.B. interpreted results of experiments; P.-A.C., S.C., C.H., P.B., D.D.K., and A.B. prepared figures; P.-A.C. and A.B. drafted manuscript; P.-A.C., S.C., X.F., and A.B. edited and revised manuscript; P.-A.C., S.C., C.H., Z.Z., P.B., D.D.K., A.P., X.F., W.N.D., and A.B. approved final version of manuscript.

\section{REFERENCES}

1. Bae EH, Ma SK, Lee J, Kim SW. Altered regulation of renal nitric oxide and atrial natriuretic peptide systems in angiotensin II-induced hypertension. Regul Pept 170: 31-37, 2011.

2. Carvalho-Filho MA, Ueno M, Hirabara SM, Seabra AB, Carvalheira JB, de Oliveira MG, Velloso LA, Curi R, Saad MJ. S-nitrosation of the insulin receptor, insulin receptor substrate 1 , and protein kinase B/Akt: a novel mechanism of insulin resistance. Diabetes 54: 959-967, 2005.

3. Choi H, Allahdadi KJ, Tostes RC, Webb RC. Augmented S-nitrosylation contributes to impaired relaxation in angiotensin II hypertensive mouse aorta: role of thioredoxin reductase. J Hypertens 29: 2359-2368, 2011.

4. Ckless K, Reynaert NL, Taatjes DJ, Lounsbury KM, van der Vliet A, Janssen-Heininger Y. In situ detection and visualization of S-nitrosylated proteins following chemical derivatization: identification of Ran GTPase as a target for S-nitrosylation. Nitric Oxide 11: 216-227, 2004.

5. Friebe A, Mergia E, Dangel O, Lange A, Koesling D. Fatal gastrointestinal obstruction and hypertension in mice lacking nitric oxide-sensitive guanylyl cyclase. Proc Natl Acad Sci USA 104: 7699-7704, 2007.

6. Giachini FR, Lima VV, Carneiro FS, Tostes RC, Webb RC. Decreased cGMP level contributes to increased contraction in arteries from hypertensive rats: role of phosphodiesterase 1. Hypertension 57: 655-663.

7. Jacke K, Witte K, Huser L, Behrends S, Lemmer B. Contribution of the renin-angiotensin system to subsensitivity of soluble guanylyl cyclase in TGR(mREN2)27 rats. Eur J Pharmacol 403: 27-35, 2000.

8. Jacke K, Witte K, Lemmer B. Mechanisms involved in the blunted nitric oxide-cGMP pathway in hypertensive TGR(mREN2)27 rats. Eur J Pharmacol 415: 27-30, 2001.

9. Jaffrey SR, Snyder SH. The biotin switch method for the detection of S-nitrosylated proteins. Sci STKE 2001: PL1, 2001.

10. Kim DD, Sanchez FA, Duran RG, Kanetaka T, Duran WN. Endothelial nitric oxide synthase is a molecular vascular target for the Chinese herb Danshen in hypertension. Am J Physiol Heart Circ Physiol 292: H2131-H2137, 2007.

11. Kimura S, Zhang GX, Abe Y. Malfunction of vascular control in lifestyle-related diseases: oxidative stress of angiotensin II-induced hypertension: mitogen-activated protein kinases and blood pressure regulation. J Pharm Sci 96: 406-410, 2004.

12. Levy BI, Ambrosio G, Pries AR, Struijker-Boudier HA. Microcirculation in hypertension: a new target for treatment? Circulation 104: 735-740, 2001.

13. Masuyama H, Tsuruda T, Kato J, Imamura T, Asada Y, Stasch JP, Kitamura K, Eto T. Soluble guanylate cyclase stimulation on cardiovascular remodeling in angiotensin II-induced hypertensive rats. Hypertension 48: 972-978, 2006.

14. Matsuno K, Yamada H, Iwata K, Jin D, Katsuyama M, Matsuki M, Takai S, Yamanishi K, Miyazaki M, Matsubara H, Yabe-Nishimura C. Nox1 is involved in angiotensin II-mediated hypertension: a study in Nox1-deficient mice. Circulation 112: 2677-2685, 2005.
15. Mollnau H, Wendt M, Szocs K, Lassegue B, Schulz E, Oelze M, Li H, Bodenschatz M, August M, Kleschyov AL, Tsilimingas N, Walter U, Forstermann U, Meinertz T, Griendling K, Munzel T. Effects of angiotensin II infusion on the expression and function of $\mathrm{NAD}(\mathrm{P}) \mathrm{H}$ oxidase and components of nitric oxide/cGMP signaling. Circ Res 90: E58-E65, 2002.

16. Nakashima H, Suzuki H, Ohtsu H, Chao JY, Utsunomiya H, Frank GD, Eguchi S. Angiotensin II regulates vascular and endothelial dysfunction: recent topics of Angiotensin II type-1 receptor signaling in the vasculature. Curr Vasc Pharmacol 4: 67-78, 2006.

17. Rajagopalan S, Kurz S, Munzel T, Tarpey M, Freeman BA, Griendling KK, Harrison DG. Angiotensin II-mediated hypertension in the rat increases vascular superoxide production via membrane NADH/NADPH oxidase activation. Contribution to alterations of vasomotor tone. J Clin Invest 97: 1916-1923, 1996.

18. Reckelhoff JF, Romero JC. Role of oxidative stress in angiotensininduced hypertension. Am J Physiol Regul Integr Comp Physiol 284: R893-R912, 2003.

19. Ruetten H, Zabel U, Linz W, Schmidt HH. Downregulation of soluble guanylyl cyclase in young and aging spontaneously hypertensive rats. Circ Res 85: 534-541, 1999.

20. Savoia C, Burger D, Nishigaki N, Montezano A, Touyz RM. Angiotensin II and the vascular phenotype in hypertension. Expert Rev Mol Med 13: e11, 2011.

21. Sayed N, Baskaran P, Ma X, van den Akker F, Beuve A. Desensitization of soluble guanylyl cyclase, the NO receptor, by S-nitrosylation. Proc Natl Acad Sci USA 104: 12312-12317, 2007.

22. Sayed N, Kim DD, Fioramonti X, Iwahashi T, Duran WN, Beuve A. Nitroglycerin-induced S-nitrosylation and desensitization of soluble guanylyl cyclase contribute to nitrate tolerance. Circ Res 103: 606-614, 2008.

23. Schulz E, Gori T, Munzel T. Oxidative stress and endothelial dysfunction in hypertension. Hypertens Res 34: 665-673, 2011.

24. Sparks MA, Parsons KK, Stegbauer J, Gurley SB, VivekanandanGiri A, Fortner CN, Snouwaert J, Raasch EW, Griffiths RC, Haystead TA, Le TH, Pennathur S, Koller B, Coffman TM. Angiotensin II type $1 \mathrm{~A}$ receptors in vascular smooth muscle cells do not influence aortic remodeling in hypertension. Hypertension 57: 577-585, 2011.

25. Stasch JP, Schmidt PM, Nedvetsky PI, Nedvetskaya TY, HSA, Meurer S, Deile M, Taye A, Knorr A, Lapp H, Muller H, Turgay Y, Rothkegel C, Tersteegen A, Kemp-Harper B, Muller-Esterl W, Schmidt HH. Targeting the heme-oxidized nitric oxide receptor for selective vasodilatation of diseased blood vessels. J Clin Invest 116: 2552-2561, 2006.

26. Takenaka H, Oshiro H, Kim DD, Thompson PN, Seyama A, Hobson RW II, Duran WN. Microvascular transport is associated with TNF plasma levels and protein synthesis in postischemic muscle. Am J Physiol Heart Circ Physiol 274: H1914-H1919, 1998.

27. Touyz RM. Reactive oxygen species and angiotensin II signaling in vascular cells-implications in cardiovascular disease. Braz J Med Biol Res 37: 1263-1273, 2004.

28. Wang HD, Xu S, Johns DG, Du Y, Quinn MT, Cayatte AJ, Cohen RA. Role of NADPH oxidase in the vascular hypertrophic and oxidative stress response to angiotensin II in mice. Circ Res 88: 947-953, 2001.

29. Weber M, Lauer N, Mulsch A, Kojda G. The effect of peroxynitrite on the catalytic activity of soluble guanylyl cyclase. Free Radic Biol Med 31: 1360-1367, 2001.

30. Whalen EJ, Foster MW, Matsumoto A, Ozawa K, Violin JD, Que LG, Nelson CD, Benhar M, Keys JR, Rockman HA, Koch WJ, Daaka Y, Lefkowitz RJ, Stamler JS. Regulation of beta-adrenergic receptor signaling by S-nitrosylation of G-protein-coupled receptor kinase 2. Cell 129: 511-522, 2007.

31. Wingler K, Wunsch S, Kreutz R, Rothermund L, Paul M, Schmidt HH. Upregulation of the vascular NAD(P)H-oxidase isoforms Nox1 and Nox 4 by the renin-angiotensin system in vitro and in vivo. Free Radic Biol Med 31: 1456-1464, 2001.

32. Zhou Z, Sayed N, Pyriochou A, Roussos C, Fulton D, Beuve A, Papapetropoulos A. Protein kinase G phosphorylates soluble guanylyl cyclase on serine 64 and inhibits its activity. Arterioscler Thromb Vasc Biol 28: 1803-1810, 2008.

33. Zweifach BW, Kovalcheck S, De Lano F, Chen P. Micropressure-flow relationships in a skeletal muscle of spontaneously hypertensive rats. Hypertension 3: 601-614, 1981. 